\title{
Epoxide ring-opening approach to the synthesis of diverse trisubstituted cyclopentanes
}

\author{
Evgeni A. Larin, ${ }^{\text {a* }}$ and Yuri M. Atroshchenko ${ }^{b}$ \\ a Organic Synthesis Laboratory, NST LLC, 20 Geroev Panfilovtsev Str., Moscow, 125480, \\ Russian Federation. \\ ${ }^{\mathrm{b}}$ Chemistry Department, L.N. Tolstoy Tula State Pedagogical University, 125 Lenin Av., Tula, \\ 300026, Russian Federation. \\ E-mail: elarin@asinex.com
}

DOI: http://dx.doi.org/10.3998/ark.5550190.p009.520

\begin{abstract}
The regiospecificity of the epoxide ring-opening reactions of (1RS,2SR,3SR)-1,2-epoxy-3-(Nbenzyl- $N$-methylamino)-cyclopentane 1 and (1RS,2SR,3SR)-1,2-epoxy-3-( $N, N$-dibenzylamino)cyclopentane 2 with $\mathrm{O}$ - and $\mathrm{C}$-nucleophiles has been explored. It has been shown that electronic and steric factors could affect the regioisomeric ratio of the products due to the possibility for a nucleophile to attack both oxirane carbon atoms. New mimics of 2-deoxystreptamine (2-DOS), the main structural motif of aminoglycoside type antibiotics, have been synthesized.
\end{abstract}

Keywords: Epoxides, regioselectivity, cyclopentanols, 2-DOS mimics

\section{Introduction}

Aminoglycosides' broad-spectrum of activity against pathogenic bacteria has favored them over the past several decades as a valuable class of antibiotics, therefore, aminoglycosides still remain important and effective therapeutics. ${ }^{1}$

The antibacterial effect of aminoglycosides is afforded mainly by their binding to the $30 \mathrm{~S}$ and $16 \mathrm{~S}$ ribosomal subunits, leading to misreading of RNA, disruption of protein synthesis and, consequently, bacterial death. ${ }^{2}$ Nevertheless, the increasing bacterial resistance to clinically important aminoglycosides, based on inactivation by modifying enzymes, ${ }^{3}$ catalyzes the search for novel aminoglycoside mimics.

The 2-deoxistreptamine (2-DOS) is a key structural moiety at the central position of almost all clinically important aminoglycoside antibiotics. ${ }^{4}$ This motif plays a crucial role in RNA recognition and biological activity. Therefore, mimicking the 2-DOS structure has been of great interest in preparing novel aminoglycoside analogs. ${ }^{5}$ 
Trisubstituted cyclopentanes represent a large and diverse class of pharmacologically important compounds. ${ }^{6-10}$ It is known that epoxide ring opening by amines is one of the common methods to synthesize a wide range of vicinal amino alcohols, the common structural components in naturally occurring and synthetic biologically active molecules. ${ }^{11-13}$ Our current research is devoted to the preparation of new 2-DOS mimics based on aminocyclopentanols as the building platform. We previously reported the stereo- and regiospecific synthesis of aminocyclopentanols applying reactions of epoxides with aliphatic amines, imidazoles and nucleobases. ${ }^{14}$ In this article we exploited the ring cleavage of 3-aminosubstituted cyclopentene oxides by $O$ - and $C$ nucleophiles.

\section{Results and Discussion}

To explore the epoxide ring-opening reactions, epoxides $\mathbf{1}$ and $\mathbf{2}$, containing substituted amino groups at $\mathrm{C} 3$ position (Scheme 1), were obtained from cyclopentene according to the procedure described earlier. ${ }^{15}$ Pyridine derivatives are found to have a large spectrum of biological activities, ${ }^{16}$ therefore, pyridin-3-ol (3-PyOH) was chosen as an $O$-nucleophile. It was established experimentally that cesium carbonate can be used as a catalyst for the ring-oprning reactions of 3substituted carbocyclic epoxides instead of sodium hydride, the common reagent for the epoxide cleavage with phenols. ${ }^{17-19}$ Cesium carbonate is easier to handle, and it is not necessarily to generate a phenolate before adding an epoxide to the reaction mixture. Additionally, this method allows to avoid overloading of the reagents in comparison with the reactions employing sodium hydride. The use of diethyl aluminium cyanide as a nucleophile in epoxide cleavage reactions ${ }^{20}$ allows to introduce a cyano group into a substrate framework, which can be converted into a carboxylic or amide functional group.

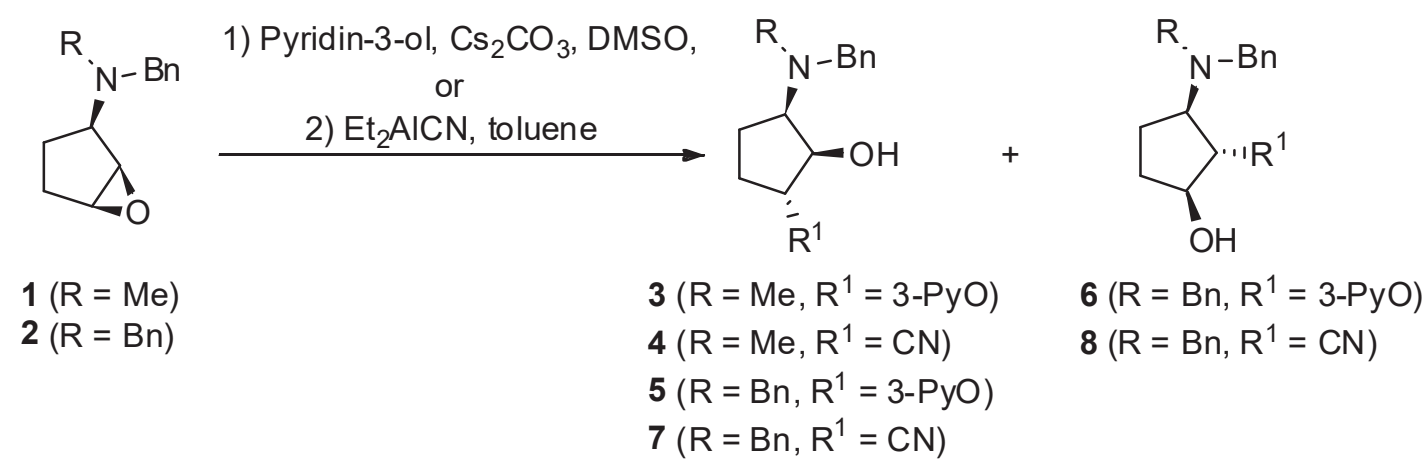

Scheme 1. Epoxide ring opening by pyridin-3-ol and $\mathrm{Et}_{2} \mathrm{AlCN}$.

Treatment of epoxide 1, bearing methyl and benzyl substituents at the nitrogen atom, with pyridin-3-ol under base catalyzed conditions ${ }^{21}$ and $\mathrm{Et}_{2} \mathrm{AlCN}$ under neutral conditions gave corresponding compounds $\mathbf{3}$ and $\mathbf{4}$ as the sole products. These reactions are regioselective, and the 
nucleophile attacks $\mathrm{C} 1$ carbon atom of the oxirane ring. On the contrary, the ring cleavage of epoxide 2, containing $N, N$-dibenzylamino moiety, under the same conditions led to the mixture of regioisomers 5:6 and 7:8 at the ratio 1:1. It has been shown earlier that the ring-opening reactions of $\mathbf{1}$ and $\mathbf{2}$ with amines in the presence of Lewis acid provided $\mathrm{C} 1$ adduct as a major product with the regioisomeric ratio $(\mathrm{C} 1: \mathrm{C} 2) 2: 1$ due to the coordination of Lewis acid on the nitrogen atom of the substituent at $\mathrm{C} 3$ carbon atom. ${ }^{14}$ Nevertheless, the nature of the amino group at $\mathrm{C} 3$ position could define the possibility for the nucleophile to attack either carbon atom of the oxirane ring.

The structure of products $\mathbf{3}, \mathbf{7}$ and $\mathbf{8}$ was established by the comparison of the methine protons multiplicity with ${ }^{1} \mathrm{H}$ NMR data for 4-6 (Table 1).

Table 1. The characteristic ${ }^{1} \mathrm{H}$ NMR data for compounds 3-8

\begin{tabular}{|c|c|c|c|c|c|}
\hline Entry & $\begin{array}{c}\text { Direction of } \\
\text { the attack }\end{array}$ & $\begin{array}{c}\text { Methine } \\
\text { proton }\end{array}$ & $\delta(\mathrm{ppm})$ & Multiplicity & $J(\mathrm{~Hz})$ \\
\hline \multirow{3}{*}{3} & \multirow{3}{*}{$\mathrm{C} 1$} & $\mathrm{C}^{2} \mathrm{H}-\mathrm{NR}_{2}$ & 2.81 & ddd & $11.1,6.9,4.4$ \\
\hline & & $\mathrm{C}^{1} \mathrm{H}-\mathrm{OH}$ & 4.08 & d & 2.9 \\
\hline & & $\mathrm{C}^{5} \mathrm{H}-\mathrm{Nu}$ & 4.61 & $\mathrm{dd}$ & $6.9,3.3$ \\
\hline \multirow{3}{*}{4} & \multirow{3}{*}{$\mathrm{C} 1$} & $\mathrm{C}^{3} H-\mathrm{NR}_{2}$ & $2.71-2.80$ & $\mathrm{~m}$ & - \\
\hline & & $\mathrm{C}^{1} H-\mathrm{Nu}$ & $2.90-2.98$ & $\mathrm{~m}$ & - \\
\hline & & $\mathrm{C}^{2} \mathrm{H}-\mathrm{OH}$ & 4.29 & dd & $4.5,2.3$ \\
\hline \multirow{3}{*}{5} & \multirow{3}{*}{$\mathrm{C} 1$} & $\mathrm{C}^{2} H-\mathrm{NR}_{2}$ & $3.08-3.16$ & $\mathrm{~m}$ & - \\
\hline & & $\mathrm{C}^{1} \mathrm{H}-\mathrm{OH}$ & 4.09 & $\mathrm{t}$ & 3.5 \\
\hline & & $\mathrm{C}^{5} \mathrm{H}-\mathrm{Nu}$ & 4.54 & $\mathrm{dd}$ & $6.1,3.7$ \\
\hline \multirow{3}{*}{7} & \multirow{3}{*}{$\mathrm{C} 1$} & $\mathrm{C}^{3} H-\mathrm{NR}_{2}$ & $2.78-2.87$ & $\mathrm{~m}$ & - \\
\hline & & $\mathrm{C}^{1} H-\mathrm{Nu}$ & 3.05 & ddd & $10.3,7.6,5.5$ \\
\hline & & $\mathrm{C}^{2} \mathrm{H}-\mathrm{OH}$ & 4.27 & $\mathrm{dd}$ & $5.8,3.7$ \\
\hline \multirow{3}{*}{6} & \multirow{3}{*}{$\mathrm{C} 2$} & $\mathrm{C}^{3} H-\mathrm{NR}_{2}$ & $3.27-3.35$ & $\mathrm{~m}$ & - \\
\hline & & $\mathrm{C}^{1} \mathrm{H}-\mathrm{OH}$ & $3.85-3.91$ & $\mathrm{~m}$ & - \\
\hline & & $\mathrm{C}^{2} \mathrm{H}-\mathrm{Nu}$ & 4.53 & $\mathrm{dd}$ & $5.3,2.1$ \\
\hline \multirow{3}{*}{8} & \multirow{3}{*}{$\mathrm{C} 2$} & $\mathrm{C}^{2} H-\mathrm{NR}_{2}$ & 2.81 & dd & $9.3,6.8$ \\
\hline & & $\mathrm{C}^{5} \mathrm{H}-\mathrm{OH}$ & 3.44 & dd & $17.3,8.4$ \\
\hline & & $\mathrm{C}^{1} \mathrm{H}-\mathrm{Nu}$ & $4.02-4.12$ & $\mathrm{~m}$ & - \\
\hline
\end{tabular}

${ }^{1} \mathrm{H}$ and ${ }^{3} \mathrm{H}$ protons of 4 appeared as the multiplets, and ${ }^{2} \mathrm{H}$ proton appeared as a doublet of doublets at $\delta 4.29$ with coupling constants 4.5 and $2.3 \mathrm{~Hz}$. This coupling pattern correlates with the number of the vicinal protons for these atoms. In ${ }^{1} \mathrm{H}$ NMR spectrum for 7 the same coupling pattern was observed. Namely, ${ }^{2} \mathrm{H}$ proton signal, that has two vicinal protons, appeared as a doublet of doublets at $\delta 4.27$ with coupling constants 5.8 and $3.7 \mathrm{~Hz}$. ${ }^{1} \mathrm{H}$ proton signals for $\mathbf{3}$ and $\mathbf{5}$, having two vicinal protons, also showed a characteristic splitting pattern and appeared as a doublet at $\delta 4.08(J 2.9$ $\mathrm{Hz}$ ) and a triplet at $\delta 4.09(\mathrm{~J} 3.5 \mathrm{~Hz})$, correspondingly.

The regio- and stereochemistry of compounds 4, 5 and 6 was carefully checked by 
bidimentional NMR methods (see Supplementary Material). Thus, the corresponding $\mathrm{H}^{5} / \mathrm{C}_{\mathrm{CN}}$, $\mathrm{H}^{5} / \mathrm{C}^{3} \mathrm{Py}$ and $\mathrm{H}^{2} / \mathrm{C}^{3} \mathrm{Py}$ correlations for 4-6 were observed in ${ }^{1} \mathrm{H}-{ }^{13} \mathrm{C} \mathrm{HMBC}$ spectra. ${ }^{2} \mathrm{H} /{ }^{3} \mathrm{H},{ }^{1} \mathrm{H} /{ }^{2} \mathrm{H}$ COSY correlations for 4 and ${ }^{1} \mathrm{H} /{ }^{2} \mathrm{H},{ }^{1} \mathrm{H} /{ }^{5} \mathrm{H}$ COSY correlations for 5 supported the interactions between the protons at the carbon atom, bearing hydroxyl, with the vicinal protons of the methine groups. In the case of product $6,{ }^{1} \mathrm{H} /{ }^{5} \mathrm{H}$ correlation, related to the interaction of the proton at $\mathrm{C} 1$ carbon atom with the protons of the methylene group, was registered. ${ }^{1} \mathrm{H} /{ }^{3} \mathrm{H}$ and ${ }^{5} \mathrm{H} /{ }^{2} \mathrm{H} 1,3-\mathrm{NOE}$ effects were absent for $\mathbf{4}$ and $\mathbf{5}$, respectively. ${ }^{1} \mathrm{H} /{ }^{3} \mathrm{H} 1,3-\mathrm{NOE}$ effect for $\mathbf{6}$ supported the interaction and the equal orientation of ${ }^{1} \mathrm{H}$ and ${ }^{3} \mathrm{H}$ methine protons. The 2D data analysis confirmed the transdiaxial opening of epoxides $\mathbf{1}$ and $\mathbf{2}$, regardless of the direction of the nucleophilic attack $(\mathrm{C} 1$ versus $\mathrm{C} 2$ ).

The synthesis of carbocyclic compounds, containing carboxylic and amide functionalities, is aimed to novel 2-DOS mimics, which may improve binding selectivity towards RNA through increased rigidity and additional hydrogen-bonding capability. ${ }^{22,23}$ The main feature of the compounds, comprising this class of 2-DOS mimics, is the presence of three functionalities amine, hydroxyl and carboxyl groups. On that basis, we performed the nitrile hydrolysis reactions using cyclopentanol 4 (Scheme 2). The application of different solvents for this reaction allowed to obtain the corresponding amide $\mathbf{9}$ and acid $\mathbf{1 0}$ with the good yields. The presence of the carboxylic group in a building block gives an additional point of variation in the generation of 2DOS mimics libraries.

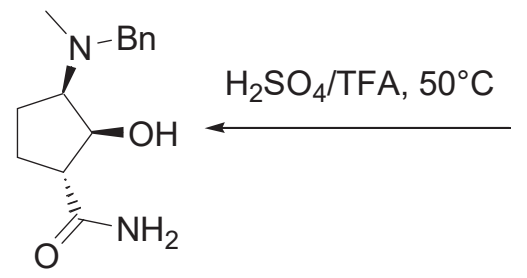

9

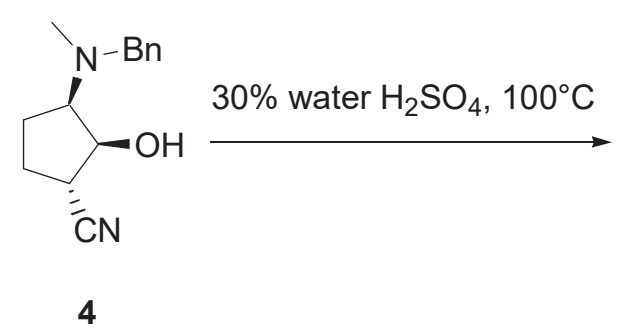

10

Scheme 2. Synthesis of amide $\mathbf{9}$ and acid $\mathbf{1 0 .}$

Based on the experimental data obtained, the regiospecificity of the oxirane ring opening reactions for $\mathbf{1}$ and $\mathbf{2}$ depends on the nature of the amino group at C3 carbon atom. It was hypothesized earlier, that the direction of a nucleophilic attack towards oxirane carbon atoms of 3 -substituted cyclopentane oxiranes is defined by the structure of the corresponding transition states. ${ }^{24,25}$ In the case of $\mathbf{1}$ and $\mathbf{2}$, the mechanism for the epoxide ring-opening reactions has been proposed (Scheme 3). The geometry of transition states 11 and 12, related to the nucleophilic attack at $\mathrm{C} 1$ or $\mathrm{C} 2$ carbon atom, suggests a distorted twist conformation. The inductive effect of both amino groups $(\mathrm{R}=\mathrm{Me}$ or $\mathrm{R}=\mathrm{Bn})$ favors the attack of the nucleophile at $\mathrm{C} 1$ oxirane carbon atom. ${ }^{26}$ On the other hand, it is assumed that the energy of transition state $\mathbf{1 1}$ is increased due to the electrostatic repulsion between the leaving group (the oxirane oxygen atom) and the vicinal substituent. This effect is more significant for five-membered carbocycles in the comparison with 
six-membered systems. ${ }^{21}$ As a result, it becomes possible for the nucleophile to attack at $\mathrm{C} 2$ carbon atom.

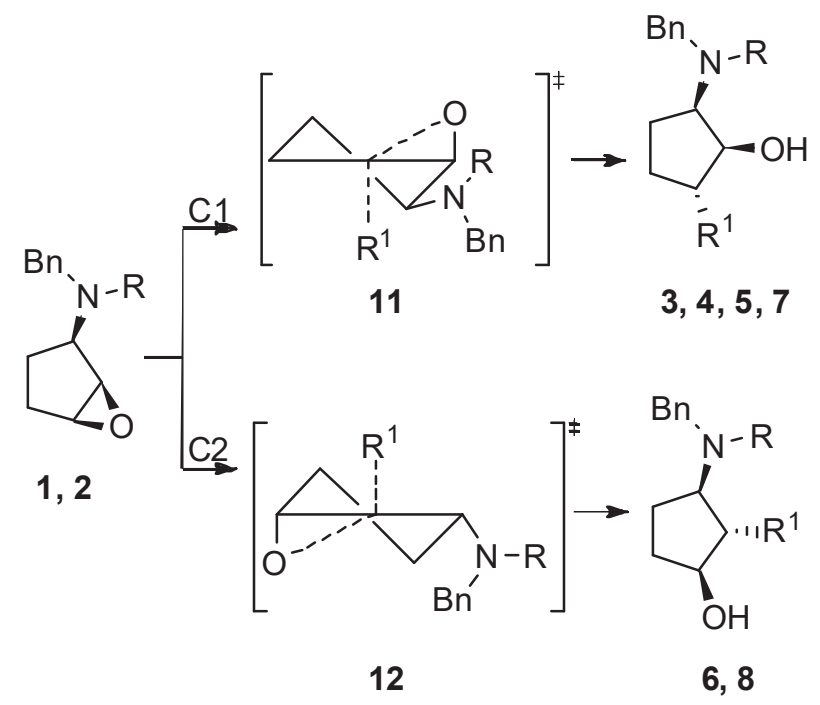

Scheme 3. Proposed mechanism for the formation of the regioisomers from epoxides $\mathbf{1}$ and $\mathbf{2}$.

As the carbon-oxygen bond begins to break at $\mathrm{C} 2$ oxirane carbon atom, the incipient positive charge at $\mathrm{C} 2$ is destabilized by the negative inductive effect of the adjacent substituent. ${ }^{27,28}$ In the case of epoxide 1, bearing methyl group at the nitrogen atom, the inductive effect of the amino moiety at $\mathrm{C} 3$ is the controlling factor, and the ring opening mainly goes through transition state $\mathbf{1 1}$ to form $\mathrm{C} 1$-adducts, regardless of steric hindrance. All the same, the electronic effect of $\mathrm{N}, \mathrm{N}$ dibenzyl amino moiety in epoxide 2 does not promote the high level of regioselectivity. As a consequence, the nucleophilic attack is possible towards both oxirane carbon atoms, and the absence of the electrostatic repulsion between the oxygen atom and the amino group in transition state 12 probably favors the attack of the nucleophile at $\mathrm{C} 2$ carbon atom. The influence of the amino moiety structure on the regiospecific outcome of this type of reactions is the issue of our further investigations.

\section{Conclusions}

The regiospecificity of the ring opening of 3-substituted 1,2-epoxycyclopentanes by $\mathrm{O}$ - and C-nucleophiles has been highlighted. A range of new 2-DOS mimics, containing pyridyl, carboxyl and amide fragments, have been synthesized. These mimics are good starting intermediates for further modification and biological investigation of aminoglycoside type antibiotics.

Cesium carbonate may serve as a catalyst for epoxide cleavage reactions with phenols. It simplifies the processes and allows to significantly scale-up the reactions of this type. A simple 
method based on the introduction of the cyano group into the cyclopentane core and the subsequent hydrolysis of the nitrile under various conditions allows to synthesize a range of new amide- and carboxylic acid-based 2-DOS mimics.

It has been shown that the structure and the inductive effect of the amino moiety at $\mathrm{C} 3$ carbon atom, along with the steric hindrance caused by the electrostatic interaction between the oxirane oxygen atom and the amino group, influence the regiospecificity of the ring opening of 3substituted 1,2-epoxycyclopentanes by nucleophiles.

\section{Experimental Section}

General. ${ }^{1} \mathrm{H},{ }^{13} \mathrm{C}$ and the detailed 2D NMR spectra were determined on Varian Mercury Plus 400 spectrometer. Chemical shifts are reported in parts per million using solvent as the internal standard (DMSO-d $\mathrm{d}_{6}$ ). LRMS was run on Finnigan Surveyor MSQ mass spectrometer. HRMS spectra were obtained on Bruker MicrOTOF II mass spectrometer. Thin layer chromatography was performed on DC-Alufoilen Kieselgel $60 \mathrm{~F}_{254} 0.2 \mathrm{~mm}$ plates (Merck) and visualized under UV light and stained with ninhydrin or Seebach solution followed by heating. Column chromatography was done by using Kieselgel 60 (Merck) 60-200 mesh as the stationary phase. All reagents and solvents were purchased from commercial sources and used without further purification. Starting epoxides $\mathbf{1}$ and $\mathbf{2}$ previously described in the literature ${ }^{15}$ were characterized by comparing their ${ }^{1} \mathrm{H}$ NMR spectra to the published data. All yields reported in this publication refer to isolated ones of compounds and their purity was determined by ${ }^{1} \mathrm{H}$ NMR. The stereochemistry displayed in the products is relative and not absolute.

General procedure for ring opening reactions of epoxides 1-2 under basic conditions as exemplified by (1RS,2RS,5RS)-2-[benzyl(methyl)amino]-5-(pyridin-3-yloxy)cyclopentanol (3). To a solution of 1 (2.04 g, $10 \mathrm{mmol})$ and pyridin-3-ol (1.24 g, $13 \mathrm{mmol})$ in DMSO (20 mL) cesium carbonate $(0.64 \mathrm{~g}, 20 \mathrm{~mol} \%)$ was added. The mixture was heated at $120{ }^{\circ} \mathrm{C}$ for $2 \mathrm{~h}$ under vigorous stirring. After completion of the reaction as monitored by TLC, the reaction mixture was diluted with $\mathrm{CH}_{2} \mathrm{Cl}_{2}(60 \mathrm{~mL})$ and water $(60 \mathrm{~mL})$. The organic layer was washed with water $(3 \times 30$ $\mathrm{mL}$ ) and dried over anhydrous $\mathrm{Na}_{2} \mathrm{SO}_{4}$. The solvent was evaporated in vacuo to give the crude product, which was purified by flash chromatography on silica gel (eluent 20\% EtOAc/hexane). Compound 3. Brown oil, yield 78\%, $2.32 \mathrm{~g} .{ }^{1} \mathrm{H}$ NMR (400 MHz, DMSO- $\left.\mathrm{d}_{6}\right): \delta_{\mathrm{H}} 1.59-1.69 \mathrm{~m}(1 \mathrm{H}$, $\left.\mathrm{CH}_{2}\right), 1.72-1.85 \mathrm{~m}\left(1 \mathrm{H}, \mathrm{CH}_{2}\right), 1.92-2.03 \mathrm{~m}\left(1 \mathrm{H}, \mathrm{CH}_{2}\right), 2.13 \mathrm{~s}\left(3 \mathrm{H}, \mathrm{NCH}_{3}\right), 2.32-2.43 \mathrm{~m}\left(1 \mathrm{H}, \mathrm{CH}_{2}\right)$, $2.81 \mathrm{ddd}\left(1 \mathrm{H}, \mathrm{C}^{2} \mathrm{H},{ }^{3} J 11.1,6.9,4.4 \mathrm{~Hz}\right), 3.53 \mathrm{~d}\left(1 \mathrm{H}, \mathrm{CH}_{2} \mathrm{Ph},{ }^{2} J 13.3 \mathrm{~Hz}\right), 3.63 \mathrm{~d}\left(1 \mathrm{H}, \mathrm{CH}_{2} \mathrm{Ph},{ }^{2} J\right.$ $13.3 \mathrm{~Hz}), 4.08 \mathrm{~d}\left(1 \mathrm{H}, \mathrm{C}^{1} \mathrm{H},{ }^{3} \mathrm{~J} 2.9 \mathrm{~Hz}\right), 4.47 \mathrm{~s}(1 \mathrm{H}, \mathrm{OH}), 4.61 \mathrm{dd}\left(1 \mathrm{H}, \mathrm{C}^{5} \mathrm{H},{ }^{3} J 6.9,3.3 \mathrm{~Hz}\right), 7.20-$ $7.35 \mathrm{~m}(5 \mathrm{H}, \mathrm{Ph}), 7.36-7.41 \mathrm{~m}\left(2 \mathrm{H}, \mathrm{C}_{5} \mathrm{H}_{4} \mathrm{~N}\right), 8.15-8.19 \mathrm{~m}\left(1 \mathrm{H}, \mathrm{C}_{5} \mathrm{H}_{4} \mathrm{~N}\right), 8.28 \mathrm{~d}\left(1 \mathrm{H}, \mathrm{C}_{5} \mathrm{H}_{4} \mathrm{~N},{ }^{3} \mathrm{~J} 2.8\right.$ $\mathrm{Hz}) .{ }^{13} \mathrm{C}$ NMR $\left(100 \mathrm{MHz}, \mathrm{DMSO}-\mathrm{d}_{6}\right): \delta_{\mathrm{C}} 26.0\left(\mathrm{CH}_{2}\right), 28.4\left(\mathrm{CH}_{2}\right), 40.0\left(\mathrm{NCH}_{3}\right), 59.6\left(\mathrm{CH}_{2} \mathrm{Ph}\right)$, $67.2\left(\mathrm{C}^{2} \mathrm{H}\right), 73.7\left(\mathrm{C}^{1} \mathrm{H}\right), 83.3\left(\mathrm{C}^{5} \mathrm{H}\right), 121.8$ and $124.1\left(\mathrm{C}_{5} \mathrm{H}_{4} \mathrm{~N}\right), 126.8,128.0$ and $128.8(\mathrm{Ph}), 138.5$ 
$\left(\mathrm{C}_{5} \mathrm{H}_{4} \mathrm{~N}\right), 139.1(\mathrm{Ph}), 141.7$ and $153.7\left(\mathrm{C}_{5} \mathrm{H}_{4} \mathrm{~N}\right)$. LC-MS (APCI): $m / z$ 299.13 [M] ${ }^{+}$. HRMS (ESI): $m / z$ calcd for $\left[\mathrm{C}_{18} \mathrm{H}_{22} \mathrm{~N}_{2} \mathrm{O}_{2}\right]^{+}: 299.1754$; found: 299.1753 .

(1RS,2RS,5RS)-2-(Dibenzylamino)-5-(pyridin-3-yloxy)cyclopentanol (5). Brown oil, yield $36 \%, 1.35$ g. ${ }^{1} \mathrm{H}$ NMR (400 MHz, DMSO-d 6$)$ : $\delta_{\mathrm{H}} 1.44-1.60 \mathrm{~m}\left(1 \mathrm{H}, \mathrm{C}^{4} \mathrm{H}_{2}\right), 1.74-1.86 \mathrm{~m}\left(2 \mathrm{H}, \mathrm{C}^{3} \mathrm{H}_{2}\right)$, 2.20-2.34 m (1H, $\left.\mathrm{C}^{4} \mathrm{H}_{2}\right), 3.08-3.16 \mathrm{~m}\left(1 \mathrm{H}, \mathrm{C}^{2} \mathrm{H}\right), 3.74 \mathrm{~d}\left(2 \mathrm{H}, \mathrm{CH}_{2} \mathrm{Ph},{ }^{2} J 14.3 \mathrm{~Hz}\right), 3.79 \mathrm{~d}(2 \mathrm{H}$, $\left.\mathrm{CH}_{2} \mathrm{Ph},{ }^{2} \mathrm{~J} 14.3 \mathrm{~Hz}\right), 4.09 \mathrm{t}\left(1 \mathrm{H}, \mathrm{C}^{1} \mathrm{H},{ }^{3} J 3.5 \mathrm{~Hz}\right), 4.54 \mathrm{dd}\left(1 \mathrm{H}, \mathrm{C}^{5} \mathrm{H},{ }^{3} J 6.1,3.7 \mathrm{~Hz}\right), 4.75 \mathrm{~d}(1 \mathrm{H}$, $\left.\mathrm{OH},{ }^{3} J 3.7 \mathrm{~Hz}\right), 7.15-7.37 \mathrm{~m}\left(12 \mathrm{H}, \mathrm{Ph}\right.$ and $\left.\mathrm{C}_{5} \mathrm{H}_{4} \mathrm{~N}\right), 8.15 \mathrm{dd}\left(1 \mathrm{H}, \mathrm{C}_{5} \mathrm{H}_{4} \mathrm{~N},{ }^{3} \mathrm{~J} 4.2,1.3 \mathrm{~Hz}\right), 8.21 \mathrm{~d}$ $\left(1 \mathrm{H}, \mathrm{C}_{5} \mathrm{H}_{4} \mathrm{~N},{ }^{3} J 2.4 \mathrm{~Hz}\right) .{ }^{13} \mathrm{C}$ NMR $\left(100 \mathrm{MHz}, \mathrm{DMSO}-\mathrm{d}_{6}\right): \delta_{\mathrm{C}} 23.7\left(\mathrm{C}^{4} \mathrm{H}_{2}\right), 27.0\left(\mathrm{C}^{3} \mathrm{H}_{2}\right), 54.7$ $\left(\mathrm{CH}_{2} \mathrm{Ph}\right), 62.4\left(\mathrm{C}^{2} \mathrm{H}\right), 73.2\left(\mathrm{C}^{1} \mathrm{H}\right), 82.5\left(\mathrm{C}^{5} \mathrm{H}\right), 121.1$ and $123.2\left(\mathrm{C}_{5} \mathrm{H}_{4} \mathrm{~N}\right), 125.8,127.2$ and 127.6 $(\mathrm{Ph}), 137.7\left(\mathrm{C}_{5} \mathrm{H}_{4} \mathrm{~N}\right), 139.3(\mathrm{Ph}), 140.9$ and $152.9\left(\mathrm{C}_{5} \mathrm{H}_{4} \mathrm{~N}\right)$. LC-MS (APCI): $m / z 375.20[\mathrm{M}]^{+}$. HRMS (ESI): $m / z$ calcd for $\left[\mathrm{C}_{24} \mathrm{H}_{26} \mathrm{~N}_{2} \mathrm{O}_{2}\right]^{+}: 375.2067$; found: 375.2063 .

(1SR,2SR,3RS)-3-(Dibenzylamino)-2-(pyridin-3-yloxy)cyclopentanol (6). Brown crystalls, yield 37\%, 1.38 g. ${ }^{1} \mathrm{H}$ NMR (400 MHz, DMSO-d $)$ : $\delta_{\mathrm{H}} 1.60-1.72 \mathrm{~m}\left(2 \mathrm{H}, \mathrm{C}^{5} \mathrm{H}_{2}\right), 1.74-1.82 \mathrm{~m}(1 \mathrm{H}$, $\left.\mathrm{C}^{4} \mathrm{H}_{2}\right), 1.86-1.98 \mathrm{~m}\left(1 \mathrm{H}, \mathrm{C}^{4} \mathrm{H}_{2}\right), 3.27-3.35 \mathrm{~m}\left(1 \mathrm{H}, \mathrm{C}^{3} \mathrm{H}\right), 3.54 \mathrm{~d}\left(2 \mathrm{H}, \mathrm{CH}_{2} \mathrm{Ph},{ }^{2} \mathrm{~J} 14.3 \mathrm{~Hz}\right), 3.65 \mathrm{~d}$ $\left(2 \mathrm{H}, \mathrm{CH}_{2} \mathrm{Ph},{ }^{2} J 14.3 \mathrm{~Hz}\right), 3.85-3.91 \mathrm{~m}\left(1 \mathrm{H}, \mathrm{C}^{1} \mathrm{H}\right), 4.53 \mathrm{dd}\left(1 \mathrm{H}, \mathrm{C}^{2} \mathrm{H},{ }^{3} J 5.3,2.1 \mathrm{~Hz}\right), 5.08 \mathrm{~d}(1 \mathrm{H}$, $\left.\mathrm{OH},{ }^{3} J 3.9 \mathrm{~Hz}\right), 7.15-7.49 \mathrm{~m}\left(12 \mathrm{H}, \mathrm{Ph}\right.$ and $\left.\mathrm{C}_{5} \mathrm{H}_{4} \mathrm{~N}\right), 8.16-8.20 \mathrm{~m}\left(1 \mathrm{H}, \mathrm{C}_{5} \mathrm{H}_{4} \mathrm{~N}\right), 8.34 \mathrm{~d}\left(1 \mathrm{H}, \mathrm{C}_{5} \mathrm{H}_{4} \mathrm{~N}\right.$, $\left.{ }^{3} J 2.8 \mathrm{~Hz}\right) .{ }^{13} \mathrm{C}$ NMR $\left(100 \mathrm{MHz}, \mathrm{DMSO}-\mathrm{d}_{6}\right): \delta_{\mathrm{C}} 22.4\left(\mathrm{C}^{4} \mathrm{H}_{2}\right), 30.8\left(\mathrm{C}^{5} \mathrm{H}_{2}\right), 54.5\left(\mathrm{CH}_{2} \mathrm{Ph}\right), 66.0$ $\left(\mathrm{C}^{3} \mathrm{H}\right), 73.8\left(\mathrm{C}^{1} \mathrm{H}\right), 86.9\left(\mathrm{C}^{2} \mathrm{H}\right), 122.0$ and $123.8\left(\mathrm{C}_{5} \mathrm{H}_{4} \mathrm{~N}\right), 126.5,127.9$ and $128.1(\mathrm{Ph}), 138.6$ $\left(\mathrm{C}_{5} \mathrm{H}_{4} \mathrm{~N}\right), 139.6(\mathrm{Ph}), 141.5$ and $154.4\left(\mathrm{C}_{5} \mathrm{H}_{4} \mathrm{~N}\right)$. LC-MS (APCI): $m / z 375.19$ [M] $]^{+}$. HRMS (ESI): $m / z$ calcd for $\left[\mathrm{C}_{24} \mathrm{H}_{26} \mathrm{~N}_{2} \mathrm{O}_{2}\right]^{+}: 375.2067$; found: 375.2056 .

General procedure for ring opening reactions of epoxides 1-2 with $\mathrm{Et}_{2} \mathrm{AICN}$ as exemplified by $(1 S R, 2 S R, 3 R S)-3$-[benzyl(methyl)amino]-2-hydroxycyclopentanecarbonitrile (4). A solution of $1(2.04 \mathrm{~g}, 10 \mathrm{mmol})$ in dry toluene $(30 \mathrm{~mL})$ was cooled to $0^{\circ} \mathrm{C}$ under argon atmosphere, and $1 \mathrm{M}$ solution $\mathrm{Et}_{2} \mathrm{AlCN}$ in toluene $(11.0 \mathrm{~mL}, 11 \mathrm{mmol})$ was added drop-wise via syringe. The mixture was stirred at room temperature for $1 \mathrm{~h}$. After completion of the reaction as monitored by TLC, the reaction mixture was cooled to $0^{\circ} \mathrm{C}$, and $\mathrm{KF} \times 2 \mathrm{H}_{2} \mathrm{O}(1.88 \mathrm{~g}, 20 \mathrm{mmol})$ was added. The mixture was stirred at room temperature for $30 \mathrm{~min}$. The formed precipitate was filtered off and washed with EtOAc $(3 \times 10 \mathrm{~mL})$. The filtrate was concentrated in vacuo, and the residue was subjected to flash chromatography on silica gel (eluent 20\% EtOAc/hexane). Compound 4. Yellow oil, yield 60\%, 1.38 g. ${ }^{1} \mathrm{H}$ NMR (400 MHz, DMSO-d 6 ): $\delta_{\mathrm{H}} 1.69-1.82 \mathrm{~m}\left(2 \mathrm{H}, \mathrm{C}^{4} \mathrm{H}_{2}\right.$ and $\left.\mathrm{C}^{5} \mathrm{H}_{2}\right)$, 1.87-2.02 m $\left(1 \mathrm{H}, \mathrm{C}^{4} \mathrm{H}_{2}\right), 2.15 \mathrm{~s}\left(3 \mathrm{H}, \mathrm{NCH}_{3}\right), 2.16-2.26 \mathrm{~m}\left(1 \mathrm{H}, \mathrm{C}^{5} \mathrm{H}_{2}\right), 2.71-2.80 \mathrm{~m}\left(1 \mathrm{H}, \mathrm{C}^{3} \mathrm{H}\right)$, 2.90-2.98 m (1H, $\left.\mathrm{C}^{1} \mathrm{H}\right), 3.52 \mathrm{~d}\left(1 \mathrm{H}, \mathrm{CH}_{2} \mathrm{Ph},{ }^{2} J 13.4 \mathrm{~Hz}\right), 3.65 \mathrm{~d}\left(1 \mathrm{H}, \mathrm{CH}_{2} \mathrm{Ph},{ }^{2} J 13.4 \mathrm{~Hz}\right), 4.29 \mathrm{dd}$ $\left(1 \mathrm{H}, \mathrm{C}^{2} \mathrm{H},{ }^{3} \mathrm{~J} 4.5,2.3 \mathrm{~Hz}\right), 4.87 \mathrm{~s}(1 \mathrm{H}, \mathrm{OH}), 7.19-7.37 \mathrm{~m}(5 \mathrm{H}, \mathrm{Ph}) .{ }^{13} \mathrm{C}$ NMR (100 MHz, DMSO$\left.\mathrm{d}_{6}\right): \delta_{\mathrm{C}} 25.9\left(\mathrm{C}^{4} \mathrm{H}_{2}\right), 26.3\left(\mathrm{C}^{5} \mathrm{H}_{2}\right), 35.0\left(\mathrm{C}^{1} \mathrm{H}\right), 40.0\left(\mathrm{NCH}_{3}\right), 59.6\left(\mathrm{CH}_{2} \mathrm{Ph}\right), 68.0\left(\mathrm{C}^{3} \mathrm{H}\right), 74.4\left(\mathrm{C}^{2} \mathrm{H}\right)$, $122.2(\mathrm{CN}), 126.8,128.0,128.8$ and $139.1(\mathrm{Ph})$. LC-MS (APCI): $m / z 231.04$ [M] $]^{+}$. HRMS (ESI): $m / z$ calcd for $\left[\mathrm{C}_{14} \mathrm{H}_{18} \mathrm{~N}_{2} \mathrm{O}\right]^{+}: 231.1492$; found: 231.1494 .

(1SR,2SR,3RS)-3-(Dibenzylamino)-2-hydroxycyclopentanecarbonitrile (7). Yellow oil, yield $25 \%, 0.77$ g. ${ }^{1} \mathrm{H}$ NMR (400 MHz, DMSO-d 6 ): $\delta_{\mathrm{H}} 1.50-1.66 \mathrm{~m}\left(1 \mathrm{H}, \mathrm{CH}_{2}\right), 1.70-1.87 \mathrm{~m}\left(2 \mathrm{H}, \mathrm{CH}_{2}\right)$, 2.05-2.18 m (1H, $\left.\mathrm{CH}_{2}\right), 2.78-2.87 \mathrm{~m}\left(1 \mathrm{H}, \mathrm{C}^{3} \mathrm{H}\right), 3.05 \mathrm{ddd}\left(1 \mathrm{H}, \mathrm{C}^{1} \mathrm{H},{ }^{3} J 10.3,7.6,5.5 \mathrm{~Hz}\right), 3.73 \mathrm{~d}$ 
$\left(2 \mathrm{H}, \mathrm{CH}_{2} \mathrm{Ph},{ }^{2} J 15.0 \mathrm{~Hz}\right), 3.77 \mathrm{~d}\left(2 \mathrm{H}, \mathrm{CH}_{2} \mathrm{Ph},{ }^{2} J 14.9 \mathrm{~Hz}\right), 4.27 \mathrm{dd}\left(1 \mathrm{H}, \mathrm{C}^{2} \mathrm{H},{ }^{3} J 5.8,3.7 \mathrm{~Hz}\right), 5.24$ $\mathrm{s}(1 \mathrm{H}, \mathrm{OH}), 7.16-7.43 \mathrm{~m}(10 \mathrm{H}, \mathrm{Ph}) .{ }^{13} \mathrm{C}$ NMR $\left(100 \mathrm{MHz}, \mathrm{DMSO}-\mathrm{d}_{6}\right): \delta_{\mathrm{C}} 24.9\left(\mathrm{CH}_{2}\right), 25.1\left(\mathrm{CH}_{2}\right)$, $34.8\left(\mathrm{C}^{1} \mathrm{H}\right), 55.1\left(\mathrm{CH}_{2} \mathrm{Ph}\right), 63.2\left(\mathrm{C}^{3} \mathrm{H}\right), 74.5\left(\mathrm{C}^{2} \mathrm{H}\right), 121.8(\mathrm{CN}), 126.2,127.7,128.0$ and 139.8 (Ph). LC-MS (APCI): $m / z 306.85[\mathrm{M}]^{+}$. HRMS (ESI): $m / z$ calcd for $\left[\mathrm{C}_{20} \mathrm{H}_{22} \mathrm{~N}_{2} \mathrm{O}\right]^{+}: 307.1805$; found: 307.1794.

(1RS,2RS,5SR)-2-(Dibenzylamino)-5-hydroxycyclopentanecarbonitrile (8). Yellow oil, yield 25\%, 0.77 g. ${ }^{1} \mathrm{H}$ NMR (400 MHz, DMSO-d 6$): \delta_{\mathrm{H}} 1.46-1.63 \mathrm{~m}\left(1 \mathrm{H}, \mathrm{CH}_{2}\right), 1.66-1.87 \mathrm{~m}\left(3 \mathrm{H}, \mathrm{CH}_{2}\right)$, $2.81 \mathrm{dd}\left(1 \mathrm{H}, \mathrm{C}^{2} \mathrm{H},{ }^{3} J 9.3,6.8 \mathrm{~Hz}\right), 3.44 \mathrm{dd}\left(1 \mathrm{H}, \mathrm{C}^{5} \mathrm{H},{ }^{3} J 17.3,8.4 \mathrm{~Hz}\right), 3.61 \mathrm{~d}\left(2 \mathrm{H}, \mathrm{CH}_{2} \mathrm{Ph},{ }^{2} J 14.2\right.$ $\mathrm{Hz}), 3.71 \mathrm{~d}\left(2 \mathrm{H}, \mathrm{CH}_{2} \mathrm{Ph},{ }^{2} J 14.2 \mathrm{~Hz}\right), 4.02-4.12 \mathrm{~m}\left(1 \mathrm{H}, \mathrm{C}^{1} \mathrm{H}\right), 5.36 \mathrm{~d}\left(1 \mathrm{H}, \mathrm{OH},{ }^{3} J 5.4 \mathrm{~Hz}\right), 7.19-$ $7.41 \mathrm{~m}(10 \mathrm{H}, \mathrm{Ph}) .{ }^{13} \mathrm{C}$ NMR (100 MHz, DMSO-d 6$)$ : $\delta_{\mathrm{C}} 23.1\left(\mathrm{CH}_{2}\right), 32.1\left(\mathrm{CH}_{2}\right), 38.2\left(\mathrm{C}^{1} \mathrm{H}\right), 53.9$ $\left(\mathrm{CH}_{2} \mathrm{Ph}\right), 63.0\left(\mathrm{C}^{2} \mathrm{H}\right), 73.4\left(\mathrm{C}^{5} \mathrm{H}\right), 121.9(\mathrm{CN}), 126.6,127.9,128.0$ and 139.2 (Ph). LC-MS (APCI): $m / z 306.85[\mathrm{M}]^{+}$. HRMS (ESI): $\mathrm{m} / z$ calcd for $\left[\mathrm{C}_{20} \mathrm{H}_{22} \mathrm{~N}_{2} \mathrm{O}\right]^{+}: 307.1805$; found: 307.1808 .

(1RS,2SR,3RS)-3-[Benzyl(methyl)amino]-2-hydroxycyclopentanecarboxamide (9). Nitrile 4 $(0.60 \mathrm{~g}, 2.5 \mathrm{mmol})$ was dissolved in $2 \mathrm{~mL}$ of the mixture of sulfur acid and trifluoroacetic acid $(\mathrm{v} / \mathrm{v}$ 1:5). The mixture was stirred at $50{ }^{\circ} \mathrm{C}$ for $5 \mathrm{~h}$. After completion of the reaction as monitored by TLC, the reaction mixture was poured into ice water. The formed precipitate was filtered off and washed subsequently with water $(3 \times 5 \mathrm{~mL})$ and diethyl ether $(3 \times 5 \mathrm{~mL})$. The product was dried in air. White crystals, yield 69\%, $0.44 \mathrm{~g} .{ }^{1} \mathrm{H}$ NMR (400 MHz, DMSO-d 6$): \delta_{\mathrm{H}} 1.59-1.73 \mathrm{~m}\left(2 \mathrm{H}, \mathrm{CH}_{2}\right)$, 1.80-1.87 m $\left(1 \mathrm{H}, \mathrm{CH}_{2}\right), 1.91-1.98 \mathrm{~m}\left(1 \mathrm{H}, \mathrm{CH}_{2}\right), 2.12 \mathrm{~s}\left(3 \mathrm{H}, \mathrm{NCH}_{3}\right), 2.62-2.71 \mathrm{~m}\left(2 \mathrm{H}, \mathrm{C}^{3} \mathrm{H}\right.$ and $\left.\mathrm{C}^{1} \mathrm{H}\right), 3.52 \mathrm{~d}\left(1 \mathrm{H}, \mathrm{CH}_{2} \mathrm{Ph},{ }^{2} J 13.3 \mathrm{~Hz}\right), 3.64 \mathrm{~d}\left(1 \mathrm{H}, \mathrm{CH}_{2} \mathrm{Ph},{ }^{2} J 13.3 \mathrm{~Hz}\right), 4.08$ br. s $(1 \mathrm{H}, \mathrm{OH}), 4.10$ dd $\left(1 \mathrm{H}, \mathrm{C}^{2} \mathrm{H},{ }^{3} J 5.0,1.4 \mathrm{~Hz}\right), 6.63$ br. s $\left(2 \mathrm{H}, \mathrm{CONH}_{2}\right), 7.17-7.38 \mathrm{~m}(5 \mathrm{H}, \mathrm{Ph}) .{ }^{13} \mathrm{C} \mathrm{NMR}(100 \mathrm{MHz}$, DMSO-d $)_{6}: \delta_{\mathrm{C}} 25.2\left(\mathrm{CH}_{2}\right), 27.3\left(\mathrm{CH}_{2}\right), 39.8\left(\mathrm{NCH}_{3}\right), 51.5\left(\mathrm{C}^{1} \mathrm{H}\right), 59.4\left(\mathrm{CH}_{2} \mathrm{Ph}\right), 68.6\left(\mathrm{C}^{3} \mathrm{H}\right), 73.6$ $\left(\mathrm{C}^{2} \mathrm{H}\right), 126.6,127.9,128.8$ and $138.9(\mathrm{Ph}), 175.7\left(\mathrm{CONH}_{2}\right)$. LC-MS (APCI): $m / z 249.04[\mathrm{M}]^{+}$. HRMS (ESI): $m / z$ calcd for $\left[\mathrm{C}_{14} \mathrm{H}_{20} \mathrm{~N}_{2} \mathrm{O}_{2}\right]^{+}: 249.1598$; found: 249.1601 .

(1RS,2SR,3RS)-3-[Benzyl(methyl)amino]-2-hydroxycyclopentanecarboxylic acid (10). Nitrile $4(0.60 \mathrm{~g}, 2.5 \mathrm{mmol})$ was dissolved in $2 \mathrm{~mL}$ of $30 \%$ water solution of sulfur acid. The mixture was stirred at $100{ }^{\circ} \mathrm{C}$ for $24 \mathrm{~h}$. After completion of the reaction as monitored by TLC, the reaction mixture was poured into ice water and neutralized with saturated water solution of sodium bicarbonate till $\mathrm{pH}$ 7. The product was extracted with the mixture of $\mathrm{CH}_{2} \mathrm{Cl}_{2}$ and isopropanol $(\mathrm{v} / \mathrm{v}$ $4: 1,5 \times 5 \mathrm{~mL}$ ). The organic layer was concentrated in vacuo, the residue was dissolved in acetonitrile $(5 \mathrm{~mL})$, and the solvent was evaporated. The formed precipitate was washed with diethyl ether $(3 \times 5 \mathrm{~mL})$ and dried in vacuo. White crystals, yield $80 \%, 0.50 \mathrm{~g} .{ }^{1} \mathrm{H}$ NMR $(400 \mathrm{MHz}$, DMSO-d $\left.{ }_{6}\right): \delta_{\mathrm{H}} 1.67-1.87 \mathrm{~m}\left(2 \mathrm{H}, \mathrm{CH}_{2}\right), 1.89-1.99 \mathrm{~m}\left(1 \mathrm{H}, \mathrm{CH}_{2}\right), 2.04-2.12 \mathrm{~m}\left(1 \mathrm{H}, \mathrm{CH}_{2}\right), 2.28 \mathrm{~s}$ $\left(3 \mathrm{H}, \mathrm{NCH}_{3}\right), 2.74-2.81 \mathrm{~m}\left(1 \mathrm{H}, \mathrm{C}^{3} \mathrm{H}\right), 2.83-2.92 \mathrm{~m}\left(1 \mathrm{H}, \mathrm{C}^{1} \mathrm{H}\right), 3.77 \mathrm{~d}\left(1 \mathrm{H}, \mathrm{CH}_{2} \mathrm{Ph},{ }^{2} J 13.2 \mathrm{~Hz}\right), 3.92$ $\mathrm{d}\left(1 \mathrm{H}, \mathrm{CH}_{2} \mathrm{Ph},{ }^{2} J 13.4 \mathrm{~Hz}\right), 4.34 \mathrm{dd}\left(1 \mathrm{H}, \mathrm{C}^{2} \mathrm{H},{ }^{3} J 4.8,1.2 \mathrm{~Hz}\right), 7.27-7.45 \mathrm{~m}(5 \mathrm{H}, \mathrm{Ph}), 8.29 \mathrm{br} . \mathrm{s}$ $(1 \mathrm{H}, \mathrm{COOH}) .{ }^{13} \mathrm{C}$ NMR $\left(100 \mathrm{MHz}, \mathrm{DMSO}-\mathrm{d}_{6}\right): \delta_{\mathrm{C}} 24.3\left(\mathrm{CH}_{2}\right), 26.3\left(\mathrm{CH}_{2}\right), 39.7\left(\mathrm{NCH}_{3}\right), 51.0$ $\left(\mathrm{C}^{1} \mathrm{H}\right), 58.7\left(\mathrm{CH}_{2} \mathrm{Ph}\right), 68.0\left(\mathrm{C}^{3} \mathrm{H}\right), 72.3\left(\mathrm{C}^{2} \mathrm{H}\right), 127.4,128.0,129.4$ and $135.8(\mathrm{Ph}), 175.0(\mathrm{COOH})$. LC-MS (APCI): $m / z 250.02[\mathrm{M}]^{+}$. HRMS (ESI): $\mathrm{m} / z$ calcd for $\left[\mathrm{C}_{14} \mathrm{H}_{19} \mathrm{NO}_{3}\right]^{+}: 250.1438$; found: 250.1438 . 


\section{References}

1. Fosso, M. Y.; Lee, Y.; Garneau-Tsodikova, S. Med. Chem. Commun. 2014, 5, 1075-1091. http://dx.doi.org/10.1039/C4MD00163J

2. Kaul, M.; Barbieri, C. M.; Pilch, D. S. J. Am. Chem. Soc. 2006, 128, 1261-1271. http://dx.doi.org/10.1021/ja056159z

3. Smith, C. A.; Baker, E. N. Curr. Drug Targets 2002, 2, 143-160. http://dx.doi.org/10.2174/1568005023342533

4. Busscher, G. F.; Rutjes, F. P. J. T.; Delft, F. L. Chem. Rev. 2005, 105, 775-791. http://dx.doi.org/10.1021/cr0404085

5. Chittapragada, M.; Roberts, S.; Ham, Y. W. Perspect. Med. Chem. 2009, 3, 21-37.

6. Saadi, F.; Arfaoui, A.; Amri, H. Syn. Commun. 2013, 43, 1594-1601. http://dx.doi.org/10.1080/00397911.2011.654371

7. Guan, Y.; Bissantz, C.; Bergstrom, D. E.; Link, A. Arch. Pharm. Chem. Life Sci. 2012, 1-10.

8. Liu, L.; Montgomery, J. Org. Lett. 2007, 9, 3885-3887. http://dx.doi.org/10.1021/o10713761

9. Zohrabi-Kalantari, V.; Jarrahian, A.; Bissantz, C.; Bergstrom, D. E.; Barker, E. L.; Link, A. Med. Chem. 2013, 9, 881-888.

http://dx.doi.org/10.2174/1573406411309060013

10. Bond, C. W.; Cresswell, A. J.; Davies, S. G.; Fletcher, A. M.; Kurosawa, W.; Lee, J. A.; Roberts, P. M.; Russell, A. J.; Smith, A. D.; Thomson, J. E. J. Org. Chem. 2009, 74, 67356748 .

http://dx.doi.org/10.1021/jo9012783

11. Bøjstrup, M.; Fanefjord, M.; Lundt, I. Org. Biomol. Chem. 2007, 5, 3164-3176. http://dx.doi.org/10.1039/b710232a

12. Dey, R. T.; Sarkar, T. K. J. Org. Chem. 2010, 75, 4521-4529. http://dx.doi.org/10.1021/jo100724w

13. Bergmeier, S. C. Tetrahedron 2000, 56, 2561-2576. http://dx.doi.org/10.1016/S0040-4020(00)00149-6

14. Larin, E. A.; Kochubei, V. S.; Atroshchenko, Y. M. Beil. J. Org. Chem. 2014, 10, $2513-$ 2520 .

http://dx.doi.org/10.3762/bjoc.10.262

15. Brennan, M. B.; Claridge, T. M. W.; Compton, R. G.; Davies, S. G.; Fletcher, A. M.; Henstridge, M. C.; Hewings, D. S.; Kurosawa, W.; Lee, J. A.; Roberts, P. M.; Schoonen, A. K.; Thomson, J. E. J. Org. Chem. 2012, 77, 7241-7261.

http://dx.doi.org/10.1021/jo3010556

16. Chaubey, A.; Pandeya, S. N. Asian J. Pharm. Clin. Res. 2011, 4, 5-8. 
17. Lier, E.; Berthold, R.; Troxler, F. Helv. Chim. Acta 1979, 62, 932-940. http://dx.doi.org/10.1002/hlca.19790620403

18. McCarthy, J. R.; Wiedeman, P. E.; Schuster, A. J.; Whitten, J. P.; Barbuch, R. J. J. Org. Chem. 1985, 50, 3095-3103.

http://dx.doi.org/10.1021/jo00217a017

19. Seyedi, S. M.; Ghaber, H. Asian J. Chem. 2004, 16, 74-84.

20. Spanevello, R. A.; Pellegrinet, S. C. Syn. Commun. 1995, 25, 3663-3670. http://dx.doi.org/10.1080/00397919508015503

21. Flessner, T.; Doye, S. J. Prakt. Chem. 1999, 341, 186-190. http://dx.doi.org/10.1002/(SICI)1521-3897(199902)341:2<186::AIDPRAC186>3.0.CO;2-6

22. Roberts, S.; Chittapragada, M.; Pendem, K.; Leavitt, B. J.; Machler, J. W.; Ham, Y. W. Tetrahedron Lett. 2010, 51, 1779-1781. http://dx.doi.org/10.1016/j.tetlet.2010.01.111

23. Vourloumis, D.; Takahashi, M.; Winters, G. C.; Simonsen, K. B.; Ayida, B. K.; Barluenga, S.; Qamar, S.; Shandrick, S.; Zhao, Q.; Hermann, T. Bioorg. Med. Chem. Lett. 2002, 12, 3367-3372.

http://dx.doi.org/10.1016/S0960-894X(02)00759-X

24. Bovenkamp, J. W.; Langstaff, E. J.; Moir, R. Y.; Bannard, R. A. B. Can. J. Chem. 1979, 57, 2444-2457. http://dx.doi.org/10.1139/v79-390

25. Langstaff, E. J.; Moir, R. Y.; Bannard, R. A. B.; Casselman, A. A. Can. J. Chem. 1968, 46, 3649-3658.

http://dx.doi.org/10.1139/v68-604

26. Parker, R. E.; Isaac, N. S. Chem. Rev. 1959, 59, 737-799.

http://dx.doi.org/10.1021/cr50028a006

27. Wolinsky, J.; Thorstenson, J. H.; Killinger, T. A. J. Org. Chem. 1978, 43, 875-881. http://dx.doi.org/10.1021/jo00399a017

28. Bannard, R. A.; Casselman, A. A.; Langstaff, E. J.; Moir, R. Y. Can. J. Chem. 1968, 46, 3542.

http://dx.doi.org/10.1139/v68-006 